Bahçe A. B., Gümüş Ö. (2015). A solution to eradicate jobless growth: meritocracy. Copernican Journal of Finance \& Accounting, 4(1), 9-25. http://dx.doi.org/10.12775/CJFA.2015.001

\author{
Abdullah Burhan Bahçe* \\ Dumlupınar University \\ ÖNER GüMüş ${ }^{* *}$ \\ Dumlupınar University
}

\title{
A SOLUTION TO ERADICATE JOBLESS GROWTH: MERITOCRACY
}

Keywords: labor market, globalization, global financial crisis, jobless growth, meritocracy, tax burden.

JEL Classification: E20, F66, H12, H21, 016, H21.

Abstract: World economy showed an important development after $9 / 11$. With the
transition of neoliberal economy programs, employment around the world had incre-
ased until 2008 global financial crisis. Because of the devastation effects of the crisis,
the increase in the employment level stopped and reached a record level in some coun-
tries after 2008 . Current appropriate economic policies are not enough because there
are some factors which arise jobless growth. For instance, globalization, labor cost, tax
burden, substitution between technology and labor, capital -intensive markets and so
on create jobless growth, particularly in developing countries. In other words, econo-
mic policies are not enough to solve unemployment problem. In addition to these poli-
cies, contemporary and qualitative approaches should be used. One of these approaches
is meritocracy. In terms of employment phenomenon, meritocracy is a notion that cre-

Date of submission: April 17, 2015; date of acceptance: May 8, 2015.

* Contact information: abdullah.bahce@dpu.edu.tr, Dumlupınar University Evliya Çelebi Campus Public Finance Department, Kütahya/Turkey, phone: +902742652031 (2126).

** Contact information: oner.gumus@dpu.edu.tr, Dumlupınar University Evliya Çelebi Campus Public Finance Department, Kütahya/Turkey, phone: +902742652031 (2104). 
ates efficiency and justice in an economy. One of the examples which creates jobless growth is globalization. Globalization has adverse effects as well as positive effects. One of the examples is a substitution between technology and labor. If there is much automation in a company, less labor is employed. And this hampers to notice talented persons who create more efficiencies than technology can do. In addition, because these talented persons are unemployed due to technology substitution, some structural conflicts can arise. Although the reasons of jobless growth are based on economic reasons, the most efficient solution is to establish a meritocratic system. By using this system, the output will become more qualified than that of now because in that case the people in the system will become more qualified. In this study, the significance of meritocracy in eradication jobless growth will be emphasized and some examples related to developing countries will be given, and from this perspective some proposals will be presented to figure jobless growth problem out by creating a meritocratic system.

\section{INTRODUCTION}

After terrorist attacks on 11 September 2011, the world has changed its direction in terms of politics and economics. For this reason economic policies become more capital-oriented. This indicated that neoliberal economic programs came into force after that time. New investments were made and employment increased. However, because the economic programs did not focus on human, the world markets were shaken and employment levels again decreased. Aftermath, employment levels have begun to increase again. Put it differently, fluctuations have been seen for a decade. These fluctuations underlie the jobless growth problem especially around developing economies.

From this perspective, in the first subject, we define the concepts of meritocracy and jobless growth to understand better the situations of developing countries. And we specify the reasons of jobless growth in the upcoming section. The importance of merit of meritocracy in economy is what we tell about in the third subject. In the discussion section, we compare unemployment and growth rates of developing countries to demonstrate jobless growth periods. After that, necessary arrangements are presented to establish a meritocratic system in developing economies to avoid economic fluctuations.

\section{THE RESEARCH METHODOLOGY}

\section{AND THE COURSE OF THE RESEARCH PROCESS}

The aim of this article is to show jobless growth occurs if there is no meritocracy. To demonstrate this fact, we will use statistical data about unemployment and growth rates of selected important countries. And we will evaluate these 
facts in terms of fairness and justice. However, the concept of meritocracy and jobless growth can be understood very well to show the relationship between meritocracy and jobless growth. For this reason, these subjects will be explained in detail. After explained these notions, the evaluation about meritocracy and jobless growth will be done. In addition, some proposals will be presented to eradicate the problem of jobless growth within the scope of meritocracy.

\section{THE CONCEPTS OF MERITOCRACY AND JOBLESS GROWTH}

Meritocracy means a link between individual toil and qualification obtained by schooling (Otero 2010, 399). In addition, race, gender, religious, class and other status indicators are not taken into account (Schmidt 2005, 130). In other words, there is no distinction between an individual's origin and his/her outcomes in life in a meritocratic system (Longoria 2006, 4). As seen in a meritocratic system justice is included. However, without equality it does not mean any sense. By saying equality, it should be understood opportunity equality so that qualified people can participate in some beneficial actions for society gain. That's why; meritocracy should be detailed to present both justice and equality.

The three Es of modern meritocracy are effort, education and exams (Radnor, Koshy, Taylor 2006, 295):

- Effort: Merit consists of IQ and attempts, meaning that meritocratic system clearly good, fair and desirable (Reynolds, Xian 2014, 122).

- Education: If a modern education is based on a selection mechanism in a meritocratic system, it is very important to provide incentives for individuals to create economic efficiency and industrial development at an aggregate level (Li 2001, 73).

- Exams: The third element of meritocracy accounts for the functionalist idea which means that discrepancies in success should be induced different rewards (Mijs 2015).

Gradstein (2004) comes up with three prepositions for the structure of meritocracy. To understand the importance of meritocracy, it becomes beneficial to evaluate these prepositions.

Firstly, if the degree of meritocracy is quite high in a society, the educational resources are distributed unevenly across individuals (Gradstein 2004, 800). Secondly, an increasing function of a child's productivity is the preferred level of meritocracy (Gradstein 2004, 801). Third preposition is that compared to democratic administration, an elite administration is willing to be more meri- 
tocratic (Gradstein 2004, 802). Theoretically, most of countries are democratic and in other countries are trying to be more democratic than that of now. And equal opportunity is for everyone. However, it is not enough for a meritocratic society. In addition, there should be justice. When these two are not realized, some structural problems can arise. One of these problems reflects on labor markets as jobless growth.

Jobless growth can be seen in that while economy grows, employment growth will take negative values or zero in an economy (Reber 2014, 5) and this can be evaluated theoretically by using labor market graphs.

Graph 1. Labor Market with Meritocracy

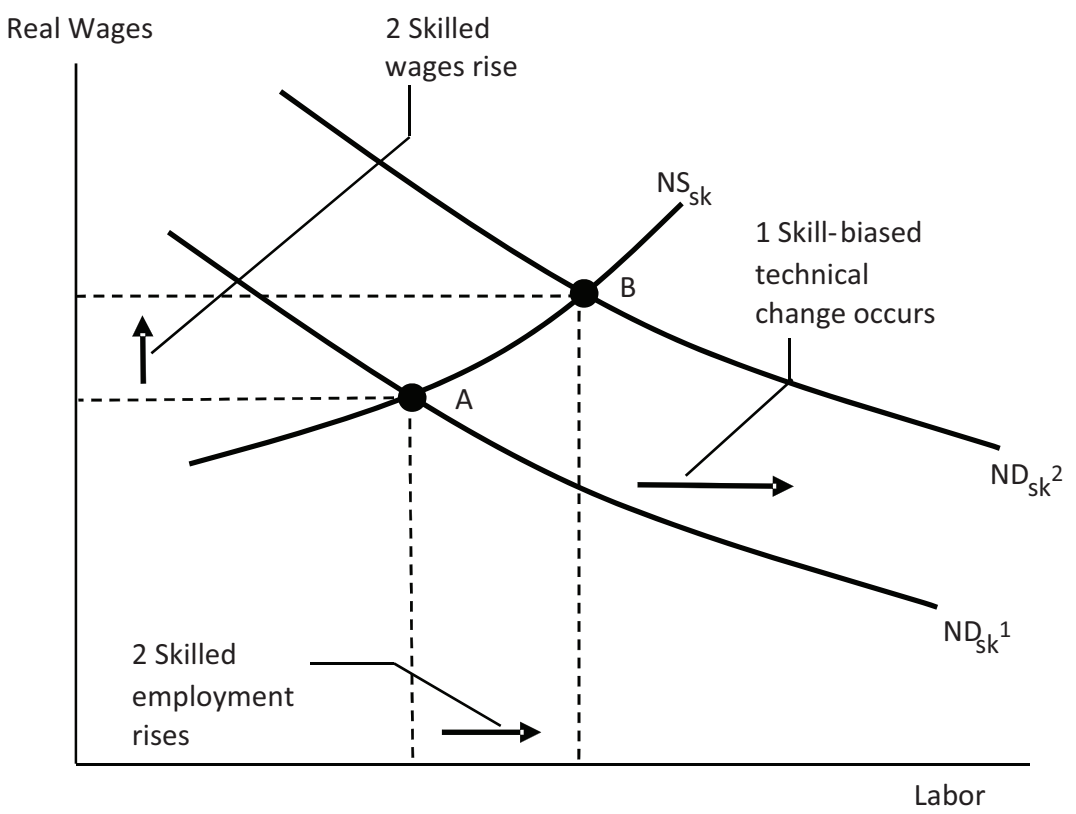

S o u r c e : Abel \& Bernanke 2001, 90.

A labor market equilibrium can change whether there is meritocracy or not in an economy. The reason of this is that meritocracy can be seen a positive supply shock. On the other hand, if there is no meritocracy in an economy, negative supply shock will be seen in labor markets. And while meritocratic systems have benevolent effects for qualified workers, in the system which is not meri- 
tocratic, unqualified workers can get advantage in entering labor market. And the outputs will change in terms of qualified and unqualified workers. Under the assumption of meritocracy is a skill-biased technical change, if meritocracy is applied, more qualified workers can enter the labor market and the employment level and real wage will increase.

Graph 2. Labor Market with no Meritocracy

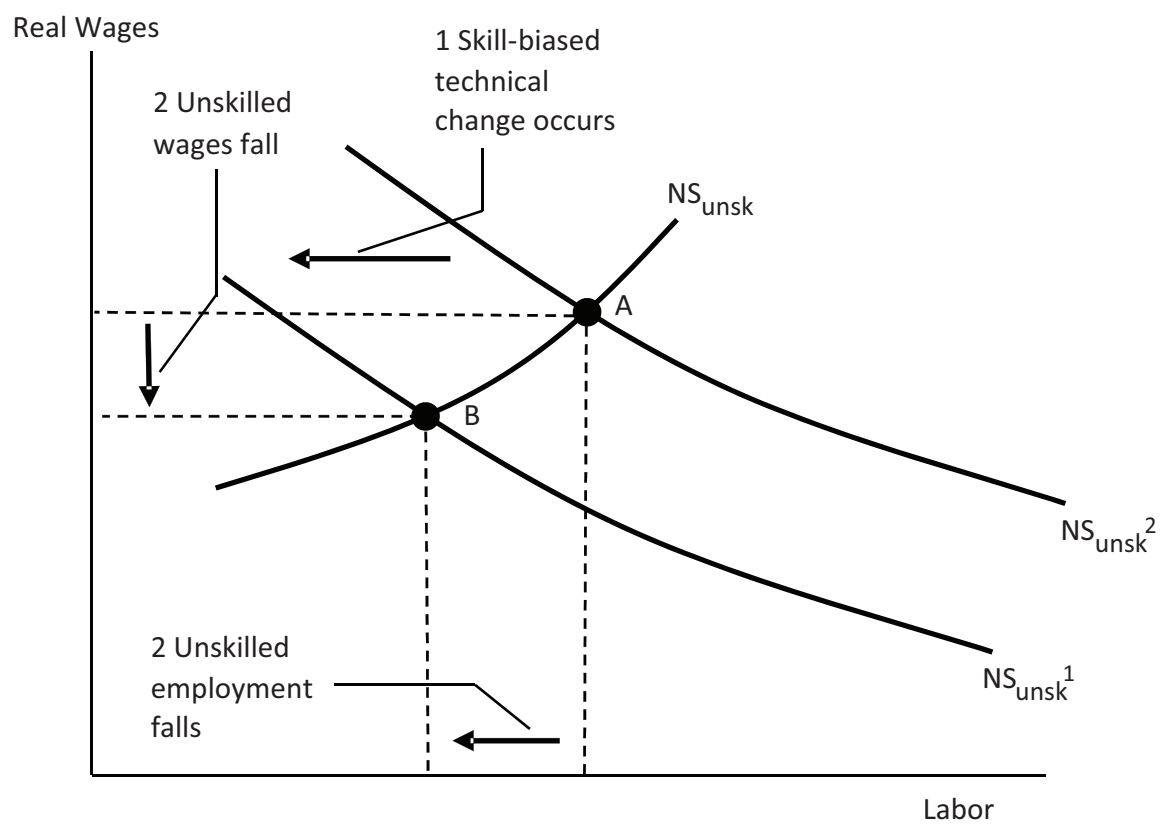

S o u r c e : Abel \& Bernanke 2001, 90.

However, there can be seen negative technical change in a society without meritocracy. In that case, most of the qualified workers are not employed and instead, unqualified workers will place in labor market. However, because qualified are not included in the labor market, the outputs which need qualified labor to produce will decrease. Although the economy will increase in initial stage, this increase cannot extend the capacity of economy. This results in excess employment and firms remove some workers to maximize their profits. Consequently, while economy grows, employment will decrease. In other words, jobless growth occurs in such kind of economy. 


\section{THE REASONS OF JOBLESS GROWTH}

The reasons of jobless growth are as follows (Çaşkurlu 2014, 46-50): Domestic saving insufficiency meets hot money, every economic growth cannot be employment-intensive, in developing countries, financial expansion and collapse period result in persistent distortion in labor markets and economic growth stages, the competition between the states which want to benefit from global capital and global capital is realized over labor price and wage, there is a substitution between technology and labor, legal arrangements are accepted as a burden for the capitalist system, social security contributions are seen as costs for the capitalists, globalization rarifies levying taxes on capital and increases tax burden for workers, outward-oriented capital markets and common financial speculative actions shrink labor-intensive sectors and increase underground economy and eradicate available job opportunities.

At microeconomic level, saving is needed for individual consume. On the other hand, savings are an indicator for future economic growth in terms of macroeconomic level (Karlan, Ratan, Zinman 2014, 36). Theoretically, the sum of consumption, investments and government purchases are equal to GDP. And it is assumed that saving and investments are equal to each other. That's why; in the case of increases of saving, it is easily said that a country grows. However, when there is insufficiency in terms of saving, and if this insufficiency is met by hot money, some problems arise in an economy like long- term unemployment.

In fragile economies, domestic saving insufficiency is meet some ways like hot money. Hot money is the money that immediately changes among financial markets in looking for the highest short term interest rate (Allen 2009, 198). In fragile economies, hot money generally takes place and for a short term economic recovery can be seen. However, because this type of investment is withdrawn when a better alternative is found, economy meets a turbulence in terms of growth and employment. Put it differently, while economic growth is seen by means of hot money, because there is no structural investment in economy, employment becomes zero or negative. This indicates that it is not a strictly link between economic growth and employment. As a result, jobless growth occurs due to domestic insufficiency.

The dynamics of capitalism play an important role to see clearly the competition between capitalists and states which want to get benefit from the capitalists' capital. 
The fundamental of dynamics in capitalism is that change in national income is equal to change in wages, change in capitalist surplus and surplus invested (Lambert, Kwon 2015, 4). For capitalists, wages are production costs. Because of this and profit maximization incentives, they always want to pay low wages. So, there will be a trade of between wage and capitalist surplus for states and capitalists. And some strategies applied by capitalists and states will arise. Each strategy has its pros and cons.

Firstly, if states present some privileges to capitalists, they can increase national income without thinking individuals' welfare. However, states sometimes behave differently. Secondly, as known, the aim of political parties is voting maximization. To realize it, they can present some facilities to voters by ignoring capitalists' stakes. Especially this type of behavior occurs before elections.

In the first strategy, even if there is a potential for individuals to find a job despite of low wages, economy can grow with an increasing employment level.

In the second strategy, because wages increase, so does national income because high wages have a potential to increase consumption. Put it differently, national income will increase. But, at the end of this process because capitalists are ignored, job opportunities will decrease and so will employment level. In one hand economy grows, but on the other hand employment level will decrease. As a result, jobless growth occurs due to competition between states and capitalists.

The aims of technology are to enable training to people for the creation of objects of value on behalf of consumers to improve active originative participation in useful activities and to improve the ability to make miscellaneous links between science and human necessities (Sasova 2014, 56). As it is seen, although technology has some beneficial features, it is sometimes used contrary to employment level. For instance, if there is much automation by means of technology, a company does not need to employ a worker and by doing so it can maximize its profit and economy can grow.

Some legal arrangements like regulation and social security contributions are acknowledged as costs for firms and this undoubtedly affects employment policies and innately employment level.

The regulation approach can help to form a connection between institutional forms and regularities of capitalist economies (Jessop 1997, 288). Due to profit maximization incentives, some firms have potential to be a natural monopoly. But this creates imperfection for lots of economies which try to form perfect competition markets. In that case regulations can be needed. 
The regulations for natural monopolies are divided into three ways (Çetin, Ölmezoğulları 2005, 45-49):

- Rate of Return Regulation: Firms gains do not exceed the service costs which are regulated. For this reason, the gains are restricted (Çetin, Ölmezoğulları 2005, 45).

- Price Cap Regulation: This type of regulation tries to enable firms some incentives to decrease its costs (Çetin, Ölmezoğulları 2005, 47).

- Incentive Regulation: This is a regulation method which is designed to enable utilities with incentives to reach specific targets, or to come across specific standards or to perform in a more economic way (Mann 1997, 4).

In a capitalist economy, there is a framework which consists of three levels. The top level is political authority, the middle level is regulators provided by political authority, regulations and institutions and the bottom level is formal markets (Scott 2011, 43). Among this system, some regulatory policies which are defined above are applied on monopolists. But monopolists generally do not like such policies since they decrease monopolist's profits. However, since these policies are formed under legal constructions, monopolists have to obey these policies. So, monopolists still contribute to economic growth but with a lower employment rate. That's why; jobless growth problem may arise in such economies.

Another example of legal arrangements is social security contributions paid by firms for workers. More employment means more social security contributions firms have to pay. Because these contributions are assumed as costs by firms, firms may be unwilling to employ new workers. In this event, employment policies become unaffected and while economy goes on growing, employment level can be zero or negative. This is another aspect of the reason related to jobless growth.

Globalization is a vigorous process and its contemporary roots are based on disruption, protectionism and wretchedness of the Great Depression. Three key elements indicate the process of globalization. First is a breaking down of international trade barriers, the second one is deregulation and privatization and the last one is international coordination (Deprez 2014, 371). These elements undoubtedly can have an effect on taxation.

The most prominent and significant effect of globalization on taxation can be seen in the taxation of capital income. Because globalization causes financial liberalization and technological improvement, financial capital elasticity is 
equal to infinite, meaning that financial capital can easily leave a country with high tax rates and move into another country with lower tax rates since there is almost no barriers (Seob 2014, 174). For this reason, the taxes which are not collected from capital gains are levied on labor and tax burden is imputed on workers. Due to financial capital mobility, while economy can grow, employment will be fixed or will decrease. The reason of decreasing employment is that tax burden causes people who want to enter labor market discourage to find a job because working becomes more costly than being unemployed. In other words, tax burden on labor causes substitution effect to be greater than income effect. Consequently, at the end of such stage, jobless growth will occur.

Capital markets which are open and financial speculation actions shrink traditional labor intensive sectors by changing economic structure. Also, they increase underground economy, suppress real sector and by this way they eradicate available job opportunities (Çaşkurlu 2014, 50).

\section{MERIT OF MERITOCRACY IN ECONOMY}

The idea of that positions are obtained on the underpinning of merit rather than the features like patronage, seniority, gender and so on is a necessary principle of modern liberal democratic governance. If there is a competition among candidates, the strongest belief is that the best one is appointed consistent with his or her ability. Another meaning of merit is related to the notion of desert and according to this meaning who deserves to appoint is the best person (Thornton 2013, 129). This best person make meritorious decisions by thinking the questions associated with legality, trustworthiness, timeliness, transparency, sustainability, morality (Godwin 2011, 318-319). However, to realize this affirmative meritocratic structure, an appropriate environment should be formed.

Two steps should be formed for such kind of meritocracy (Walton, Spencer, Erman 2013, 11-22):

- Creation of an environment which excludes biased thoughts;

- Regarding the hidden ability in acceptance and employing.

Biased thoughts prevent selecting a qualified worker for the critical position in both public and private sectors. In private sector, main aim is profit maximization. To do this, this sector employs qualified workers. Think that it would not employ such workers. Instead, employment policies would consist of subjective criteria indicated above. This is nepotism and the end of nepotism is inefficiency. That's why; for this association there would be two options. First 
is that it takes a risk to go bankruptcy. Theoretically, because the main aim is profit maximization, the owner does not desire this option. Another option is that the owner lays the worker off whom he hires according to biased thoughts. In that case, the owner can go on his way and he forms new employment policies which provide employing qualified workers.

In public sector, main aim is to provide services to its citizens. However, it doesn't matter whether you realize most of services or not because other workers who are unqualified earn the same salary. But for a party which wants to maximize its votes, employing qualified workers is a better way to make voting maximization. And employing workers according to biased thoughts prevent workers from revealing his or her hidden ability. In addition, such a state turns into an autocratic state.

To avoid such implications, main argument should be "S Merits X in virtue of M" where S is person, X is outcome and M is ability possessed by M (McCrudden 1998, 547). Suppose that $S$ knows treating cancer (namely M). In that case $\mathrm{S}$ gets a high salary (X) above labor market equilibrium price. If employment policies should be like in this example, efficient-driven labor market will arise. To deserve $\mathrm{X}$, however, people should have equal opportunity. That's why; meritocracy should be rest on two ways which was practiced in $19^{\text {th }}$ century in England to be a superior system (Madan 2007, 3045):

- Efficiency Argument: Selection should be accurate. In other words, there cannot be uncertain points in employing workers.

- Equality Argument: A pool should be form and all population places in there to be selected the best.

These two arguments are strictly necessary. But, equality in opportunity is also necessary to operate the economic system efficiently. With private and public sectors which are full of qualified workers, an economy operates efficiently and jobless growth cannot be seen.

\section{DiscusSION}

The jobless growth problem can be analyzed by examining growth rates and unemployment rates of developing economies: 
Table 1. Unemployment rate as percentage

\begin{tabular}{|l|c|c|c|c|c|c|c|c|c|c|c|c|c|}
\hline \hline \multicolumn{1}{|c|}{ Countries } & $\mathbf{2 0 0 2}$ & $\mathbf{2 0 0 3}$ & $\mathbf{2 0 0 4}$ & $\mathbf{2 0 0 5}$ & $\mathbf{2 0 0 6}$ & $\mathbf{2 0 0 7}$ & $\mathbf{2 0 0 8}$ & $\mathbf{2 0 0 9}$ & $\mathbf{2 0 1 0}$ & $\mathbf{2 0 1 1}$ & $\mathbf{2 0 1 2}$ & $\mathbf{2 0 1 3}$ & $\mathbf{2 0 1 4}$ \\
\hline \hline Turkey & 9.7 & 9.9 & 9.6 & 9.5 & 9.0 & 9.1 & 10.0 & 13.0 & 11.1 & 9.1 & 8.4 & 9.0 & 9.9 \\
\hline Japan & 5.3 & 5.2 & 4.7 & 4.4 & 4.1 & 3.8 & 3.9 & 5.0 & 5.0 & 4.5 & 4.3 & 4.0 & 3.6 \\
\hline Mexico & 2.8 & 2.9 & 3.6 & 3.4 & 3.5 & 3.6 & 3.9 & 5.3 & 5.3 & 5.1 & 4.9 & 4.9 & 4.9 \\
\hline New Zealand & 5.3 & 4.7 & 4.0 & 3.8 & 3.8 & 3.6 & 4.1 & 6.1 & 6.5 & 6.5 & 6.8 & 6.1 & 5.5 \\
\hline Hungary & 5.8 & 5.8 & 6.0 & 7.1 & 7.4 & 7.3 & 7.8 & 10.0 & 11.1 & 10.9 & 10.9 & 10.2 & 7.8 \\
\hline Israel & 12.7 & 13.2 & 12.8 & 11.2 & 10.4 & 9.1 & 7.7 & 9.4 & 8.3 & 7.1 & 6.8 & 6.2 & 6.0 \\
\hline Portugal & 5.0 & 6.2 & 6.6 & 7.5 & 7.6 & 7.9 & 7.5 & 9.4 & 10.7 & 12.6 & 15.5 & 16.1 & 13.7 \\
\hline Estonia & 11.1 & 10.4 & 10.0 & 7.9 & 5.9 & 4.5 & 5.5 & 13.4 & 16.5 & 12.2 & 10.0 & 8.6 & 7.3 \\
\hline Slovenia & 6.3 & 6.6 & 6.2 & 6.5 & 5.9 & 4.8 & 4.3 & 5.8 & 7.2 & 8.1 & 8.8 & 10.1 & 9.9 \\
\hline Greece & 10.3 & 9.7 & 10.5 & 9.9 & 9.0 & 8.3 & 7.7 & 9.6 & 12.7 & 17.8 & 24.4 & 27.4 & 26.4 \\
\hline \hline
\end{tabular}

S o u r c e : http://stats.oecd.org/index.aspx?queryid=51396 (accessed: 07.03.2015).

Table 2. Growth rate as percentage

\begin{tabular}{|l|c|c|c|c|c|c|c|c|c|c|c|c|c|}
\hline \hline \multicolumn{1}{|c|}{ Countries } & $\mathbf{2 0 0 2}$ & $\mathbf{2 0 0 3}$ & $\mathbf{2 0 0 4}$ & $\mathbf{2 0 0 5}$ & $\mathbf{2 0 0 6}$ & $\mathbf{2 0 0 7}$ & $\mathbf{2 0 0 8}$ & $\mathbf{2 0 0 9}$ & $\mathbf{2 0 1 0}$ & $\mathbf{2 0 1 1}$ & $\mathbf{2 0 1 2}$ & $\mathbf{2 0 1 3}$ & $\mathbf{2 0 1 4}$ \\
\hline \hline Turkey & 6.1 & 5.2 & 9.3 & 8.4 & 6.8 & 4.6 & 0.6 & -4.8 & 9.1 & 8.7 & 2.1 & 4.1 & 2.9 \\
\hline Japan & 0.2 & 1.6 & 2.3 & 1.3 & 1.6 & 2.1 & -1.0 & -5.5 & 4.6 & -0.4 & 1.4 & 1.5 & 0.3 \\
\hline Mexico & 0.1 & 1.4 & 4.0 & 3.2 & 4.9 & 3.1 & 1.1 & -4.4 & 5.1 & 4.0 & 3.7 & 1.3 & 2.5 \\
\hline New Zealand & 4.8 & 4.3 & 4.3 & 2.6 & 2.2 & 3.3 & -0.6 & 0.6 & 1.8 & 1.1 & 2.6 & 2.5 & 3.1 \\
\hline Hungary & 4.4 & 3.7 & 4.7 & 4.2 & 3.9 & 0.5 & 0.8 & -6.5 & 0.7 & 1.8 & -1.4 & 1.5 & 3.3 \\
\hline Israel & -0.1 & 1.0 & 5.0 & 4.3 & 5.6 & 6.1 & 3.9 & 1.5 & 5.7 & 4.1 & 2.9 & 3.3 & 2.5 \\
\hline Portugal & 0.7 & -0.9 & 1.8 & 0.7 & 1.5 & 2.4 & 0.1 & -2.9 & 1.8 & -1.8 & -3.3 & -1.3 & 0.8 \\
\hline Estonia & 6.1 & 7.4 & 6.4 & 9.4 & 10.4 & 7.9 & -5.3 & -14.7 & 2.4 & 8.2 & 4.6 & 1.6 & 2.0 \\
\hline Slovenia & 3.8 & 2.8 & 4.3 & 4.0 & 5.6 & 6.9 & 3.3 & -7.7 & 1.2 & 0.6 & -2.6 & -0.9 & 2.1 \\
\hline Greece & 3.1 & 6.5 & 4.8 & 1.1 & 5.7 & 3.3 & -0.4 & -4.3 & -5.3 & -8.8 & -6.6 & -3.9 & 0.8 \\
\hline \hline
\end{tabular}

S o u r c e : http://stats.oecd.org/index.aspx?queryid=51396 (accessed: 07.03.2015).

When it is looked to the data above, it is easily seen that most of the breaking point is the year of 2009. The reason of this case is global financial crisis. That's why; this also shows that most of the developing economies are fragile and it 
should be searched for how to avoid such kind of cases. But, firstly, it is examined the jobless growth periods of developing countries.

Although there are strong job opportunities, unemployment increases because labor force in Turkey enlarges quickly (World Bank 2014). In addition, after 2010, Turkey established new universities and graduated people have been attending to labor force. These reasons shed light on why Turkey has jobless growth at the term 2012-2013. While growth rate increase - from $2.1 \%$ to $4.1 \%$-, unemployment rate $-8.4 \%$ to $9.0 \%$ - will decrease in this period.

Labor market in Japan has calmly retrieved in return for triggering fiscal stimulus and sequential economic growth (Organization for Economic Cooperation and Development 2014, 1). In addition, it has a strong economy. However, global financial crisis affected this economy. In terms of jobless growth, from 2008 to 2009 while growth rate increases, the employment rate will be almost fixed, meaning that jobless growth problem occurred in Japan.

In Mexico, a global retardation started at the end of 2001 and this had an important effect on economic actions of Mexico. Domestic sources of Mexico were insufficient for third reasons: First reason is insufficient level and quality of investment after 1995 and the second reason is credit squeeze after peso crisis, and the third reason is that high interest rates adversely affected investments. As a result, employment became fragile and the income was low and unstable (Organization for Economic Cooperation and Development 2004, 3839). For these reasons, Mexico had some adverse economic implications like jobless growth. Because while growth rate increased from $0.1 \%$ to $1.4 \%$, the unemployment rate raised from $2.8 \%$ to $2.9 \%$. After that time, Mexico showed an important GDP growth rate which raise from $1.4 \%$ to $4.0 \%$.

Nonetheless, labor force grew rapidly in Mexico. In other words to say, Mexico economy did not meet this capacity (Organization for Economic Cooperation and Development 2005, 29), meaning that despite of the increase in GDP, unemployment rate increased from $2.9 \%$ to $3.6 \%$ in 2003-2004 term. Put it differently, Mexico had jobless growth again.

After global financial crisis, Mexican government presented an anti-crisis package for unemployment. (Organization for Economic Cooperation and Development 2009a, 35). This case reflected to employment level and unemployment rate stayed constant while GDP growth rate increasing sharply from $4.4 \%$ to $5.1 \%$. So that, Mexico had jobless growth problem at the term of 2008-2009.

In 2012, a package reform, known as "Pacte por México", was accepted to reach a welfare position in economy (Organization for Economic Cooperation and 
Development 2015, 4). From this perspective, if examined, it is seen that GDP growth rate increased from $1.3 \%$ to $2.5 \%$ whilst unemployment rate remained same. To sum up, Mexico experienced jobless growth four times in its $21^{\text {st }}$ economic history.

In terms of income level and output, New Zealand showed a successful trend until 2007. However, this process shifted adversely after 2007. The international oil prices increased sharply, maintained high domestic growth pressed capacity, monetary policy was tightened, capital gains slowed, drought problem arouse and finally in 2008 growth rate was negative (Organization for Economic Cooperation and Development 2009b, 21). After that time, economy recovers in terms of GDP growth increased from $-0.6 \%$ to $0.6 \%$, but unemployment rate increased from $4.1 \%$ to $6.1 \%$ for the term of $2008-2009$. After that, the effects of crises went on and while GDP growth rate increased from $0.6 \%$ to $1.8 \%$, the unemployment rate rose from $6.1 \%$ to $6.5 \%$. Next year, GDP growth rate decreased. However, in the term of 2011-2012 GDP growth rate increased from $1.1 \%$ to $2.6 \%$ with an increased unemployment rate from $6.5 \%$ to $6.8 \%$.

Hungary has also three experiences about jobless growth. The first term is 2003-2004. Growth rate increased from $5.8 \%$ to $6.0 \%$ in that time, and unemployment rate increased too from $3.7 \%$ to $4.7 \%$. The second term is $2007-2008$. Growth rate increased from $0.5 \%$ to $0.8 \%$. And the last jobless growth period is 2009-2010 which growth rate increased from $-6.5 \%$ to $0.7 \%$ as unemployment rate increased from $10.0 \%$ to $11.1 \%$.

Israel lived jobless growth in the period of 2002-2003. Growth rate increased from $-0.1 \%$ to $1.0 \%$. In addition, Estonia had jobless growth problem just one term like Israel. After global financial crisis, growth rate increased from $-14.7 \%$ to $2.4 \%$ and unemployment rate also increased from $13.4 \%$ to $16.5 \%$. Another similar country is Slovenia in which growth rate increased $-7.7 \%$ to $1.2 \%$ as long as unemployment rate arouse from $5.8 \%$ to $7.2 \%$, meaning that it had a jobless growth at that time.

Portugal demonstrated an interesting portrait. First jobless growth problem was experienced in 2003-2004 which growth rate increased from $-0.9 \%$ to $1.8 \%$ as unemployment rate increased from $6.2 \%$ to $6.7 \%$. The second one in 2005-2006 which growth rate increased $0.7 \%$ to $1.5 \%$ as unemployment rate increased from $7.5 \%$ to $7.6 \%$. The third experience is $2009-2010$ which growth rate increased from $-2.9 \%$ to $1.8 \%$ as unemployment rate increased from $9.4 \%$ to $10.7 \%$. And the last one is the period of $2012-203$ which growth rate rose from $-3.3 \%$ to $-1.3 \%$ as unemployment raised from $15.5 \%$ to $16.1 \%$. 
The last country is Greece. Greece has two experiences about jobless growth. In the period of 2011-2012, growth rate increased from $-8.8 \%$ to $-6.6 \%$ as unemployment rate raised $17.8 \%$ to $24.4 \%$. The second one is the period of 2012-2013. In this time, growth rate increased from $-6.6 \%$ to $-3.9 \%$. At the same time unemployment rate rose from $24.4 \%$ to $27.4 \%$.

As seen above, every developing economy experienced jobless growth at least one time. However, the most remarkable point is that every economy has fluctuations in terms of growth and unemployment.

\section{CONCLUSION}

Because fluctuations have potential to rise jobless growth problem, one of the main and strong system - a meritocratic system - should be formed. However, some points ought to be materialized to from this system. These necessities are as follows:

- Exams or interviews should be fair: Exams and interviews are mostly selected methods to employ qualified workers. If these methods are used unfairly, some undesirable results can be turned up. These undesirable results lead to inefficiencies in both public and private sectors. If these inefficiencies turn up in private sector, most of firms can go bankruptcy and the government can intervene to private sector to provide equilibrium both for consumers and producers. On the other hand, if these inefficiencies turn up in public sector, important conflicts can arise in society and this can follow even a government change because equilibrium is also in public sector as well as in private sector.

- Democracy standards should be high: Democracy contains freedom and freedom brings creativity in personal ability. And a creative worker can produce qualified outputs. But this is not limited to workers. This is valid also for firms. In a freedom economic environment, perfect competition markets emerges and in a perfect competition markets, output quality will be better than that of previous situation.

- Equal Opportunity should be presented to every individual: There is elitism in a society which does not include equal opportunity. Both the rich and the poor should obtain the same opportunities to prove their abilities. With equal opportunity principle, skilled but poor people can circumvent from poverty and gain status. As a result, such kind of societies can reach welfare and do not experience economic fluctuations. 
- Autocratic private and public structures should be destroyed: Autocracy always presses people to show their abilities. The reason of this is that autocratic structures behave in a fordist manner. Put it differently, individualism is absorbed. However, people should be creative to be obtained desirable results or outputs. Thus, they should be behaved in a post-fordist manner. For instance, working conditions should be flexible. A worker should not fell himself or herself under pressure. Rather, the main focus ought to be on producing qualified output.

- Extreme utility maximization should be prevented: In a fair society, every individual has right to maximize its utility for both private and public sector. Nonetheless, in some extreme cases, there can be schism. And inefficient outputs result form these schism movements since these movements place important cornerstones in public and private sectors.

- Promotions should be realized by using tax structures: Regardless of the qualified or the unqualified, all workers pay income taxes. And the income tax means a decrease in disposable income for individuals. Income taxes can be used for qualified workers as an incentive. Moreover, this can cause for unqualified workers to increase their capacities. By this way, disposable income can be increased and both fairness and equality can be reached. The only condition for this is to change tax structures efficiently. In addition, Pareto optimum is enabled because qualified workers have potential to increase a country's production possibilities.

Meritocracy can be accepted as a merit good. After realizing the above, with this merit good, economic fluctuations are vanished thereby eradicating jobless growth. Consequently, a desirable, equal and fair society can be reached.

\section{REFERENCES}

Abel A. B., Bernanke B. S. (2001), Macroeconomics, $4^{\text {th }}$ edn, AddisonWesley Longman, USA.

Allen L. (2009), The Encyclopedia of Money, $2^{\text {nd }}$ edn, ABC-CLIO, California.

Çaşkurlu E. (2014). İstihdamsız Büyüme (İstihdamsız İyileşme) Sorununa Karşı Kamusal Politikalar ve Önemi. Türkiye Açısından Bir Değerlendirme, Amme İdaresi Dergisi, 47(2), 43-76.

Çetin T., Ölmezoğulları N. (2005). Doğal Tekeller, Regülasyonu ve Rekabetçi Uygulamalar, İktisat İşletme ve Finans, 20(232), 36-55. http://dx.doi.org/10.3848/ iif.2005.232.9172.

Deprez J. (2014). International Tax Policy: Recent Changes and Dynamics Under Globalization. Journal of Post Keynesian Economics, 25(3), 367-384. 
Godwin A. (2011). Merit and Merits in the Public Service: Are We Confusing the Baby with the Bathwater?. The Australian Journal of Public Administration, 70(3), 318-326. http://dx.doi.org/10.1111/j.1467-8500.2011.00732.x.

Gradstein M. (2004). Voting on Meritocracy. European Economic Review, 48(4), 797-803. http://dx.doi.org/10.1016/j.euroecorev.2003.07.001.

Jessop B. (1997). Survey Article: The Regulation Approach. The Journal of Political Philosophy, 5(3), 287-326. http://dx.doi.org/10.1111/1467-9760.00036.

Karlan D., Ratan A. L., Zinman J. (2014). Savings by and for the Poor: A Research Review and Agenda. Review of Income and Wealth Series, 60(1), 36-78. http://dx.doi. org/10.1111/roiw.12101.

Lambert T. E., Kwon E. (2015). Monopoly Capital and Capitalist Inefficiency. International Review of Applied Economics, 1-20. http://dx.doi.org/10.1080/02692171.2 015.1016409 .

Li B. (2001), Manufacturing Meritocracy: Adult Education, Career Mobility, and Elite Transformation in Socialist China, PhD thesis, Graduate Studies of Stanford University, Stanford.

Longoria R. T. (2006), Meritocracy and Americans' Views on Distributive Justice, PhD thesis, Graduate School of the University of Maryland, Maryland.

Madan A. (2007). Sociologising Merit. Economic and Political Weekly, 42(29), 3044-3050 .

Mann P. C. (1997), Assessing the Applicability of Selected Financial Incentive Regulation Methods for Water Utility Regulation, 1-52, http://www.ipu.msu.edu/library/pdfs/nrri/Mann-Financial-Incentive-Regulation-97-9-Feb-97.pdf (accessed: 05.03.2015).

McCrudden C. (1998). Merit Principles. Oxford Journal of Legal Studies, 18(4), 543-579.

Mijs J. J. B. (2015). The Unfulfillable Promise of Meritocracy: Three Lessons and Their Implications for Justice in Education. Social Justice Research. http://dx.doi. org/10.1007/s11211-014-0228-0.

Organization for Economic Cooperation and Development 2004, OECD Economic Surveys-Mexico, vol. 2003, OECD Publication Service.

Organization for Economic Cooperation and Development 2005, OECD Economic Surveys-Mexico, vol. 2005, OECD Publication Service.

Organization for Economic Cooperation and Development 2009a, OECD Economic Surveys-Mexico, vol. 2009, OECD Publication Service.

Organization for Economic Cooperation and Development 2009b, OECD Economic Surveys: New Zealand, vol. 2009/4, OECD Publication Service.

Organization for Economic Cooperation and Development 2014, How Does Japan Compare, September 2014, OECD Employment Outlook.

Organization for Economic Cooperation and Development 2015, OECD Economic Surveys-Mexico, January 2015, OECD Publication Service.

Otero M. S. (2010). Education, Meritocracy and Redistribution. Journal of Education Policy, 25(3), 397-413. http://dx.doi.org/10.1080/02680930903576396. 
Radnor H., Koshy V., Taylor A. (2006). Gifts, Talents and Meritocracy. Journal of Education Policy, 22(3), 283-299. http://dx.doi.org/10.1080/02680930701269186.

Reber J. D. (2014). Essays on the Changing Nature of Business Cycle Fluctuations: A State Level Study of Jobless Recoveries and the Great Moderation, PhD thesis, University of Arkansas, Fayetteville.

Reynolds J., Xian H. (2014). Perceptions of Meritocracy in the Land of Opportunity. Research in Social Stratification and Mobility, 36(2014), 121-137. http://dx.doi.org/10.1016/j.rssm.2014.03.001.

Sasova I. A. (2014). Technological Education or Labor Training? Russian Education \& Society, 53(6), 49-65. http://dx.doi.org/10.2753/RES1060-9393530604.

Schmidt S. L. (2005), Juggling The Contradictions: An Exploration of White College Students' Understanding of Meritocracy and Racial Inequality, PhD thesis, Graduate School of the University of Massachusetts, Amherst.

Scott B. R. (2011), Capitalism-Its Origins and Evolution as a System of Governance, Springer-Verlag, New York.

Seob H. Y. (2014). Globalization, Institutions and Tax Reforms. Korean Review of Public Administration, 3(2), 171-200. http://dx.doi.org/10.1080/12264431.1998.108 04913.

Thornton M. (2013). The Mirage of Merit. Australian Feminist Studies, 28(76), 127-143. http://dx.doi.org/10.1080/08164649.2013.789584.

Walton G. M., Spencer S. J., Erman S. (2013). Affirmative Meritocracy. Social Issues and Policy Review, 7(1), 1-35. http://dx.doi.org/10.1111/j.1751-2409.2012.01041.x.

World Bank (2014), Turkey Regular Economic Note, December 2014, IBRD-IDA, https:// www.worldbank.org/content/dam/Worldbank/document/eca/turkey/WB_TREN_ 2014_2_03042014_ENG.pdf (accessed: 07.03.2015).

http://stats.oecd.org/index.aspx?queryid=51396 (accessed: 07.03.2015). 